\title{
Association Between Osteoarthritis and Water Fluoride Among Tongyu Residents, China 2019: A Case-control of Population-based Study
}

\section{Alphonse Sowanou}

Harbin Medical University https://orcid.org/0000-0001-6594-2240

\section{Xinyue Meng}

Harbin Medical University School of Public Health

\section{Nan Zhong}

Harbin Medical University School of Public Health

\section{Yongzheng Ma}

Harbin Medical University School of Public Health

\section{Ailin Li}

Harbin Medical University School of Public Health

\section{Jian Wang}

Harbin Medical University School of Public Health

\section{Hanying Li}

Harbin Medical University School of Public Health

Junrui Pei ( $\nabla$ pjr2003@126.com )

Harbin Medical University School of Public Health https://orcid.org/0000-0002-9469-9566

\section{Research}

Keywords: Osteoarthritis, knee Osteoarthritis, fluoride, water fluoride, China

Posted Date: July 22nd, 2021

DOI: https://doi.org/10.21203/rs.3.rs-714382/v1

License: (c) (1) This work is licensed under a Creative Commons Attribution 4.0 International License. Read Full License

Version of Record: A version of this preprint was published at Biological Trace Element Research on September 28th, 2021. See the published version at https://doi.org/10.1007/s12011-021-02937-2. 


\section{Abstract}

Background: Fluoride is an environmental chemical that has adverse effects on health, probably increasing osteoarthritis $(\mathrm{OA})$ risk. However, whether fluoride is a serious risk factor for $O A$ is still inconsistent among current evidence. The aim of this study was to determine the relationships between chronic fluoride exposure and OA risk among the residents living in Tongyu County, China 2019.

Method: 186 cases and 186 controls aged 26 to 86 years were recruited after $x$-ray examination with Kellgren and Lawrence criteria by two independent evaluators. Urinary fluoride (UF) in a spot sample was measured by fluoride ion-selective electrode, and water fluoride data were used as community level of exposure. Associations between fluoride exposure and OA risk were examined by the unconditional logistic regression. Covariates included age, gender, body mass index, duration of living, daily water drunk, income, sport and filter use with stratified analysis.

Results: Mean UF concentration $2.54 \pm 1.22 \mathrm{mg} / \mathrm{L}$ was higher than the mean of community water fluoride concentration $1.49 \pm 0.32 \mathrm{mg} / \mathrm{L}$. The mean UF concentration $2.73 \pm 1.18 \mathrm{mg} / \mathrm{L}$ was significantly higher in cases compared to $2.35 \pm 1.24 \mathrm{mg} / \mathrm{L}$ in controls group $(p<0.02)$. In full sample analysis, a $1 \mathrm{mg} / \mathrm{L}$ increase in UF level was associated with a $27 \%$ higher risk of OA ( $95 \% \mathrm{Cl}: 1.06-1.52, p=0.008)$, and $4^{\text {th }}$ quartile participants were associated with higher risk when compared to $1^{\text {st }}$ quartile (OR: $2.46,95 \% \mathrm{Cl}$ : $1.34-4.57, p=0.003)$. In stratified analysis, compared to $1^{\text {st }}$ quartile, $4^{\text {th }}$ quartile participants were 4 times more likely to have OA ( $95 \% \mathrm{Cl}: 1.86-8.82, p=0.000)$ in the non-obese group, 7.7 times more likely to have OA (95\% Cl: $2.58-25.05, p=0.000)$ among adults $\leq 60$-year and 12 times more likely to have OA (95\% Cl: $2.15-99.65, p=0.008)$ in non-obese adult women $\leq 60$-year group.

Conclusion: Water fluoride exposure may increase OA risk and could have more impact on a specific group such as non-obese and adult $\leq 60$-year population.

\section{Introduction}

Fluoride is an element that can be found in the air, rocks, soil, and water and it is both beneficial and harmful to our body[1-2]. It is a leading cause of fluorosis which is a global public health problem. The global prevalence of fluorosis is still unclear, but the World Health Organization estimated that excessive fluoride concentration in drinking water has caused tens of millions of cases of skeletal and dental fluorosis around the world over one year period [3]. Fluorosis is worldwide in distribution and endemic in approximatively 50 countries including Africa, Asia, Europe, North and South America [4]. Fluorosis is a crippling disease that results from the deposition of fluoride in the hard and soft tissues of the body; it is caused by excess intake of fluoride through drinking water/food products/industrial pollutants over a long period [5-8]. Skeletal fluorosis (SF), known as musculoskeletal disease is endemic in China, India, Mexico, and Argentina, and is generally linked to drinking well water or tea with high fluoride [9].

SF manifests by chronic joint pain, backache, stiffness and rigidity of the spine, calcification of ligaments, physical limitations, inadequate labor capacity, and disability according to the stage of 
evolution [10-13]. These symptoms are very similar to osteoarthritis (OA), making diagnosis more difficult. As Roschger's team concluded in 1995, SF can be a very sneaky disease highlighting the difficulty of its diagnostic [14]. Many observations made in the endemic areas suggested that fluoride can damage articular cartilage and even worsen OA's symptoms, and the most recent and of particular importance was done in Turkey 2001 [15-16]. OA is the most chronic and prevalent ageing joint disease which does not have an effective treatment proven to delay disease progression. Individual with OA experiences pain, stiffness, swelling, and disability [17-18]. According to the findings from the Global Burden of Disease Study 2017, approximately 61.2 million individuals were suffering from OA in China [19].

Fluoride has a well-known adverse effects on health, but the relationship between fluoride exposure and OA occurrence is not yet established. However, several studies have provided clues to a probable link between fluoride and OA. Thus, some works including radiological analysis studies and total arthroplasty studies for the treatment of hip and knee severe OA due to fluorosis reported that extensive degenerative changes in articular cartilage could occur in a patient with fluorosis [15, 20-22]. An ecological study in fluorosis-afflicted area (China) found that, the incidence of OA in the fluorosis area was remarkably higher than in either the adjacent non-endemic area or the nation as a whole [23]. Additionally, another ecological study in which 56 endemic fluorosis patients were matched to age and sex 40 non-endemic control patients suggested that endemic fluorosis may increase the severity of knee OA and cause OA before SF is obvious. According to study, the radiological severity of knee OA and osteophytes sign were significantly higher in endemic fluorosis group than in controls group [16]. Meanwhile, US health authorities still assume that fluoride does not cause arthritis symptoms before the traditional bone changes (osteosclerosis) of fluorosis are evident on x-ray [24]. Moreover, the US National Research Council review concluded that only fluoride at high therapeutic doses can cause nodules in articular cartilage not at environmental doses [25]. This because of the conflicting results showed in two reports of fluoride at therapeutic doses in rheumatoid patients. In one report [26], fluoride exacerbated rheumatoid arthritis symptoms, but, it was well tolerated in another case [27]. Despite all the observations and reports on the possible association between fluoride and OA, it appears that the evidence is not consistent enough and still at hypothesis generating level.

The belief that fluoride is associated with OA has not been fully explored and the few works found in literature are only ecologic and case-report studies. Therefore, to address this weakness, we conducted a population-based case-control study in 2019 with purpose of evaluating whether fluoride chronic exposure is associated with the risk of $\mathrm{OA}$ in population in order to strengthen epidemiological evidence.

\section{Materials And Methods}

\section{Study population and design}

A population-based case-control study with two-step recruitment was carried out in Tongyu County (Baicheng city), Jilin province, as one of fluoride endemic areas in China. In the first part of the 
recruitment, four towns in Tongyu County were investigated from November 2019 to January 2020 using cluster sampling. We used stratified random sampling to recruit $26-86$ years old permanent residents at least 10 years (640 participants). All participants were born and raised in the local area. Subjects with incomplete data, rheumatoid arthritis, prior joint injury and trauma (22 participants) were excluded. In the second part, 372 participants from the remaining 618 were selected according to the x-ray examination by two independent evaluators from two different regions. We defined a subject as having radiographic $\mathrm{OA}$ when the Kellgren and Lawrence grade was $\geq 2$ in at least 1 knee or 1 elbow. The first 186 OA cases and 186 controls diagnosed at the same time by both radiologists were retained (see additional file, figure 1). Sample size was calculated from an online Open Source Epidemiologic Statistics for Public health [28], with $59.03 \%$ as OA prevalence from the fluorosis-afflicted area in China [23] with the desired confidence interval $(\mathrm{Cl})$ of $95 \%$.

\section{Collection of data, biological and radiological samples}

Participants were investigated through face to face interview using a structured questionnaire administered uniformly by trained study physicians. The questionnaire included: demographic information, anthropometric measures, drinking water information, health status, diet and behaviors; calcium and vitamin D supplementation information.

About $50 \mathrm{~mL}$ spot urine samples (non-standard collection and first-catch urine in the morning) were collected from each participants in precleaned, labelled polythene tubes. All samples were kept in a cooled ice box and then sent immediately to laboratory. Samples were stored at $-20 \circ \mathrm{C}$ until analysis.

For all consenting participants, a single standing, anteroposterior radiograph of both knee and elbow was performed in the Baicheng central hospital. We selected knee and elbow OA subtype in this study because both joints sites are the most frequently reported in the endemic area $[16,29]$. Also knee OA is the most frequent in normal situation and again with severe complications [30-31].

\section{Fluoride exposure analysis}

The 2019 national surveillance analysis of endemic fluorosis showed that fluoride concentration for Tongyu communities' water samples ranged from 0.94 to $2.30 \mathrm{mg} / \mathrm{L}$ ( $1.49 \mathrm{mg} / \mathrm{L}$ as mean) while China's national standard limit is $1.2 \mathrm{mg} / \mathrm{L}$ (GB5749-2006). The population of Tongyu is mainly supplied by 5 water sources namely: 2 public tap water, 1 public shaft water, personal wells and bottled water. An individual's fidelity to a single water source is very rare and residents arbitrarily change their water source up to 3 in the same year or after a period of time. Hence we considered UF as the consistent and reliable parameter for measuring fluoride exposure at the individual level. UF has been shown to be an accurate evaluation of fluoride ingestion on a population basis [32].

Urine fluoride content was measured at the Key Lab of Etiology and Epidemiology, Center for Endemic Disease Control, Harbin Medical University by fluoride ion-selective electrode. The operating process was performed according to the China standard for determination of fluoride in urine [33]. We added $5 \mathrm{~mL}$ 
ionic strength adjustment buffer to each urine sample $(5 \mathrm{~mL})$ for controlling the $\mathrm{pH}$ of the solution at 5.0 - 5.5 to optimize the determination conditions. Samples were retested twice and the mean value of each sample was used for analysis.

Community water fluoride concentration 2019 data was obtained from the local Center for Endemic Disease Control of Baicheng city, Jilin province China and served as an ecologic measure of exposure.

\section{X-ray examination}

The X-Ray films were evaluated by an experienced radiologist. Each knee and elbow was evaluated for the presence of lateral or medial osteophytes, joint space narrowing, sclerosis and cysts. Both joint were also graded for overall evidence of radiographic OA according to the Kellgren and Lawrence criteria (grade 0 to 4 , where $0=$ none; 1 = possible osteophytes only; 2 = definite osteophytes and possible joint space narrowing; 3 = moderate osteophytes and or definite joint space narrowing; and 4 = large osteophytes, severe joint space narrowing, and or bony sclerosis) [34]. We defined cases as radiographic $\mathrm{OA}$ if they had a Kellgren/Lawrence grade of $\geq 2$. The radiologist had no knowledge about the participants ages and their names.

To ensure the reliability of the diagnosis, all films were brought to the radiological unit of the $2^{\text {nd }}$ affiliated hospital outpatient's department of Harbin Medical University. They were then read by an experienced, academically based bone and joint radiologist using the same Kellgren and Lawrence criteria. Only the films with $\mathrm{OA}$ diagnosis from both radiologists were accepted and considered for this study.

\section{Potential confounders and effect modifiers}

Several studies have found age, gender and obesity to be clearly associated with the occurrence of OA as person level risk factor including a recent systematic and meta-analysis study which included 88 studies [30, 35-37]. They reported that OA risk increases in female group, obese group and with age. Some dietary factor such as calcium and vitamin D have been suspected to be associated with OA [37]. Calcium and vitamin $\mathrm{D}$ supplementation information were collected by the questionnaire.

\section{Ethics statement}

This study was approved by the Ethical Review Board of Harbin Medical University (HMUIRB20120021). The study has obtained the necessary approvals from the authorities of Baicheng city. Written informed consent was obtained from each participant of the study population.

\section{Statistical analysis}

All statistical analyses were performed using R software version 4.0.3 [38]. Two-tailed $p<0.05$ was used for all tests as Significance Level. 
The Body Mass Index (BMI) was calculated according to height and weight by the formula: BMI $(\mathrm{kg} / \mathrm{m} 2)=$ weight $/$ height^${ }^{\wedge}$. Population characteristics of cases and controls were compared applying Student's t-test for continuous variables and Chi-squared test for categorical variable. We presented the results as mean with standard deviation (SD), number and percent as appropriate. Odds ratio (OR) along with their $95 \% \mathrm{Cl}$ were derived from all logistic regression models and presented. Based on the characteristics of the study population and the literature, age, gender, BMI, duration of living, daily water drunk, income, sport and filter use were selected as confounding and or third factors.

Unconditional logistic regression was used to assess the association between fluoride exposure and the risk of OA. To have a better understanding of the quantitative relationship between fluoride exposure and OA risk, we used UF as continuous variable, dichotomous variable (with $2.38 \mathrm{mg} / \mathrm{L}$ median concentration as cut-off value) and UF as ordinal variable (UF quartile: $1^{\text {st }} \mathrm{Q}$ group from 0.35 to 1.61 $\mathrm{mg} / \mathrm{L}, 2^{\text {nd }} \mathrm{Q}$ group from 1.61 to $2.38 \mathrm{mg} / \mathrm{L}, 3^{\text {rd }} \mathrm{Q}$ group from 2.38 to $3.30 \mathrm{mg} / \mathrm{L}$ and $4^{\text {th }} \mathrm{Q}$ group from 3.30 to $7.01 \mathrm{mg} / \mathrm{L}$ ) in simple logistic regression analysis. Subsequently, we kept UF as an ordinal and continuous variable in multiple logistic regression analysis.

To limit confounding/effect modifiers influence and explore the independent effect of fluoride exposure, we performed stratified analysis by gender, age, and BMI, and UF was used as an ordinal variable. Multiple logistic regression analysis was done in full sample and stratified group according to gender, age and BMI. Age was divided into two group, adult $\leq 60$-year old and adult over 60-year. BMI variable was divided into two groups no-obese and obese using Chinese diagnosis criteria of obesity (noobese $\mathrm{BMI}<27 \mathrm{~kg} / \mathrm{m} 2$ and obese $\mathrm{BMI} \geq 27 \mathrm{~kg} / \mathrm{m} 2$ ). To evaluate the magnitude of fluoride effect in these specific groups, we performed further stratified analysis in non-obese adult women $\leq 60$-year (age $\leq 60$ years \& BMl $<27 \mathrm{~kg} / \mathrm{m} 2$ \& female sex). Due to collinearity issue, we did not include age and duration of living in the model at the same time.

\section{Results}

\section{Demographic characteristics}

A total of 372 participants from which 186 cases and 186 controls were enrolled in this study. Mean UF concentration $2.54 \pm 1.22 \mathrm{mg} / \mathrm{L}$ was higher than the mean of community water fluoride concentration $1.49 \pm 0.32 \mathrm{mg} / \mathrm{L}$. The mean UF concentration $2.73 \pm 1.18 \mathrm{mg} / \mathrm{L}$ was significantly higher in cases compared to $2.35 \pm 1.24 \mathrm{mg} / \mathrm{L}$ in controls group $(p<0.02)$. Besides, the mean age was significantly higher in cases compared to that in controls (63.22 \pm 7.71 years versus $58.77 \pm 10.23$ years). The population characteristics in cases and controls were summarized and compared in Table 1. Sample descriptive statistics for fluoride exposure and OA subtype rate are shown in Table 2 and 3 respectively.

\section{Assessing association between fluoride exposure and OA outcome}

In simple logistic regression analysis shown in Table 4, from model 1(UF as continuous variable), higher UF concentrations were associated with higher odds of getting OA (OR: 1.30, 95\% Cl: $1.09-1.55, p=$ 
0.003). In other words, a $1 \mathrm{mg} / \mathrm{L}$ increase in UF level was associated with $30 \%$ higher risk of getting $O A$ diagnosis in this sample. Model 2 (UF as dichotomous variable) shows that high level group (HLG) subjects were associated with $68 \%$ higher risk of getting OA as compared to low level group (LLG) subjects (OR: $1.68,95 \% \mathrm{Cl}: 1.11-2.53, p=0.013$ ). For model 3 (UF as ordinal variable), the risk of getting $\mathrm{OA}$ increased with increasing fluoride concentration by category $(\leq 1.61,1.61-2.38,2.38-3.30,>3.30$ $\mathrm{mg} / \mathrm{L}$ ). Among the $2^{\text {nd }}, 3^{\text {rd }}$, and $4^{\text {th }}$ quartiles, the odds of getting $O A$ for the $3^{\text {rd }}$ and $4^{\text {th }} \mathrm{Q}$ group was nearly 2 times and more than 2.5 time the odds as compared to the $1^{\text {st }} \mathrm{Q}$ group reference respectively (OR: 1.87, $95 \% \mathrm{Cl}: 1.05-3.38, p=0.034$ and OR: $2.55,95 \% \mathrm{Cl}: 1.42-4.63, p=0.001)$.

In the multiple logistic regression analysis (Table 5), after adjusting for duration of living, daily water drunk, income, sport and filter use covariates, we found that $3^{\text {rd }}$ and $4^{\text {th }} \mathrm{Q}$ group were associated with higher risk of getting $\mathrm{OA}$ as compared to $1^{\text {st }} \mathrm{Q}$ group reference (OR: 1.84, 95\% Cl: $1.01-3.39, p=0.048$; OR: $2.51,95 \% \mathrm{Cl}: 1.37-4.67, p=0.003$ respectively). However, when the set of factors sex, age and BMI were introduced, only $4^{\text {th }} \mathrm{Q}$ subjects were associated with a significant risk of getting OA (OR: $2.46,95 \%$ Cl: $1.34-4.57, p=0.003$ ). Using UF as continuous variable (table 6 ), we found after adjustment for all covariates that a $1 \mathrm{mg} / \mathrm{L}$ increase in UF level was associated with $27 \%$ higher risk of getting OA (OR: $1.27,95 \% \mathrm{Cl}: 1.06-1.52, p=0.008)$.

\section{Evaluation of gender, age and BMI-specific association}

In stratified analysis adjusted for covariates shown in Table 7, sex did not modify the association between fluoride exposure and $\mathrm{OA}$. The $4^{\text {th }} \mathrm{Q}$ participants were associated with higher risk of $\mathrm{OA}$ in female as well as in male group when compared to $1^{\text {st }} \mathrm{Q}$ participants after adjustment (OR: $2.18,95 \% \mathrm{Cl}$ : $1.01-4.79, p=0.048$; OR: 4.76, 95\% Cl: $1.59-15.30, p=0.006$ respectively). Before and after adjustment for covariates, body weight modified association between fluoride exposure and OA such that $4^{\text {th }} \mathrm{Q}$ participants were associated with higher risk of getting OA when compared to $1^{\text {st }} \mathrm{Q}$ participants among non-obese group (OR: 4.21, 95\% Cl: 2.07 - 8.84, $p=0.000 ;$ OR: 3.99, 95\% Cl: $1.86-8.82, p=0.000$ respectively). Age modified association between fluoride exposure and $O A$ in such a manner that, before adjustment $4^{\text {th }} \mathrm{Q}$ participants were 6 times more likely to have $O A$ and 7.7 times after adjustment as compared to $1^{\text {st }} \mathrm{Q}$ participants in adult $\leq 60$-year group (OR: 6.00, 95\% Cl: $2.34-16.41, p=0.000$; OR: $7.69,95 \% \mathrm{Cl}: 2.58-25.05, p=0.000$ respectively). We did not find any significant association between fluoride exposure and $\mathrm{OA}$ in obese and adult over 60-year group.

To explore the magnitude of fluoride effect in these specific sub-groups, we performed further stratified analysis in non-obese adult women $\leq 60$-year (Table 7). We found a very strong association, such that before adjustment, $4^{\text {th }} \mathrm{Q}$ participants were 10 times more likely to have $\mathrm{OA}$ and after adjustment 12 times more likely to have OA disease as compared to $1^{\text {st }} Q$ participants (OR: $10.22,95 \%$ Cl: $2.24-59.29, p=$ 0.004; OR: 12.55, 95\% Cl: $2.15-99.65, p=0.008$ respectively).

\section{Discussion}


To the best of our knowledge, this is the first case-control study exploring the relationship between chronic water fluoride exposure and OA outcome in human. To date, only two ecological studies $[16,23]$ really attempted to link fluoride exposure to the induction of OA, showing how much data is lacking to discuss this topic. We examined the association between fluoride and OA risk among residents living in Tongyu County (Baicheng city, Jilin province China), an endemic area where water fluoride ranged from 0.94 to $2.30 \mathrm{mg} / \mathrm{L}$, and adjusted for factors that can influence fluoride exposure/metabolism as well as OA outcome. Instead of water fluoride exposure rate at individual level, we were able to assess exposure at community level and used UF as biomarker due to the long-term exposure with unchanged residence place. UF has been demonstrated as a precise assessment of fluoride ingestion on a population basis [32].

We found in logistic regression analysis that a $1 \mathrm{mg} / \mathrm{L}$ increase in UF level was associated with a $27 \%$ higher risk of getting OA disease after adjustment. With UF as an ordinal variable, OA risk increased with increasing fluoride concentration by category. The participants in the 4th quartile were associated with a higher risk $(\mathrm{OR}=2.55)$ of getting $\mathrm{OA}$ disease as compared to the $1 \mathrm{st}$ quartile group reference. The association remained significant after adjustment for confounding $(\mathrm{OR}=2.46)$. These results suggest that fluoride exposure from water source could be a serious independent predictor of OA, particularly as UF concentration increases in an individual, the risk of developing OA increases. Given the scarcity of data on the topic, additional and cohorts studies are needed to carefully explore this eventuality.

Articular chondrocytes in the joint is one of the key chondrocytes cell types that may be subject to pathological changes. Most of the fluoride in the body, about $99 \%$ is contained in bone in form of hydroxyapatite crystals [25]. Logically, mineral precipitates containing fluoride could occur in a joint if the concentration of fluoride and other cations such as calcium, magnesium and aluminum achieved a very high concentration. As reported by Bang et al. in 1985 [39], a case of 74 years old female who was on fluoride therapy for osteoporosis for 30 months had developed a layer of calcified cartilage containing $3.9 \mathrm{mg} / \mathrm{kg}$ by ash weight in her femoral head. This underlines the possibility that excess fluoride can cause damage to the joints. Likewise, in a study evaluating patient's groups with a greater number of subjects, Duell and Chesnut [26] found that the use of fluoride at therapeutic doses in rheumatoid patients exacerbated symptoms of rheumatoid arthritis. Another explanation may be the inhibition of osteoblast cell activity. Fluoride stimulates bone cell proliferation by direct inhibition of osteoblastic acid phosphatase activity [40] and by enhancing the mitogenic signals of growth factors [41-42]. The activity of osteoblast cell produces a huge increase in bone formation at the organ level, producing exostoses, calcification of tendons and ligaments, and osteosclerosis [42]. In the most recent time study from Savas et al. [16], it was demonstrated that patients with skeletal fluorosis had a greater severity of knee OA symptoms and osteophyte formation than age and sex-matched control group patients. In our study, OA proportion increased as UF level increased by category. Everything suggests that people exposed to fluoride have an additional risk of developing OA, even if the entire mechanism is not yet clear. The development of OA relies on an interaction between several factors and so this process may be considered as the final product of an interplay between systemic and local factors, genetics and 
imbalance in the physiological process [43-44], which may give the possibility to fluoride to play a certain role knowing that its target tissue is bone and cartilage [25, 39].

Any increase of OA risk in the obese group, female group and with ageing could be of particular concern because they have been established with an elevated risk [35-37]. We also explored group specific association and found that a non-obese adult woman $\leq 60$-year with UF $>3.30 \mathrm{mg} / \mathrm{L}$ is associated with 12.55 times greater odds of getting OA disease as compared to one with UF $\leq 1.61 \mathrm{mg} / \mathrm{L}$. This suggests that, being an adult woman $\leq 60$-year and non-obese at the same time is a factor that could allow chronic water fluoride exposure to considerably increase OA risk. Given the lack of studies on the topic, further investigations are needed to draw any conclusion, although association has been estimated in more detail in each group.

After dividing age into two groups of adult $\leq 60$-year of age and adult over 60 -year, we found an increased risk of OA in adult $\leq 60$-year group. Before adjustment, 4th quartile participants were 6 times more likely to have $\mathrm{OA}$ when compared to $1 \mathrm{st}$ quartile participants. The association remained even more stronger and significant after adjustment (OR: 7.7). This surprising association could suggest that, an adult under 60-years old is at increased risk (sevenfold) of developing OA once exposed to fluoride as compared to an adult over 60-years old. Bone fluoride concentration tend to increase with age due to the continuous accumulation over time [45-46]. The potential reason for this is the preferential removal of crystallites with little or no fluoride in the elderly [25]. One would have expected an increased risk of OA in adults over 60-years age group as a result. May be the wear and tear of joints structure due to ageing is too evolved to be affected by the additional effect of fluoride, perhaps there is an intervention of other unknown factors.

In the non-obese group analysis, the 4th quartile participants were 4.21 times more likely to have OA as compared to the 1st quartile participants. Association remained significant after adjustment with 3.99 greater odds of getting OA in 4th quartile participants. Meanwhile, no significant association was observed in the obese group. This result could mean that, in the fluoride exposure context, only the nonobese group is at increased risk of OA. It seems that obesity is a stage of impairment where the fluoride effect does not have too much influence. However, additional studies are needed for more exploration as data are sparse. Fluoride adverse effect depends on the magnitude and the length of exposure, and how it behaves in the body, whereas the mechanisms underlying its metabolism and biological effects are not clearly understood yet [47]. Any environmental, biochemical, physiological, and pathological condition which interferes with the absorption or excretion of fluoride, will influence its destiny in the body and may ultimately increase the risk of musculoskeletal disorders [48].

\section{Limitations}

One limitation of our study is the measurement of exposure rate at the individual level. Even if we measure the concentration of UF for every participant, this may not be directly related to the community water. Of course, the source of exposure is from community water, but there might probably be some 
unidentified additional sources of exposure contributing to the exposure rate at the individual level as demonstrated by the difference between mean UF $(2.54 \pm 1.22 \mathrm{mg} / \mathrm{L})$ and mean community water fluoride $(1.49 \pm 0.32 \mathrm{mg} / \mathrm{L})$. At this point, we were unable to measure the other sources of exposure such as: toothpaste, consumed foods and products locally made, and tea consumption. Different level of exposure should be taken into account in futures investigations. We observed a close relationship between fluoride exposure and OA outcome with some group specific associations (non-obese and adult $\leq 60$-year group). However, this may not mean any causal inference. Therefore, these results should be interpreted with caution. Also, the cross-sectional nature of our study does not allow us to easily state a direction of the association between fluoride exposure and OA outcome. Given this limitation and the scarcity of evidence on the topic, our findings should be viewed along with others and as hypothesis testing. Ultimately, we recommend more prospective studies with a large sample size as possible to deeply explore the influence of fluoride exposure on OA outcome.

The strength of our study is that we used radiographic OA rather than self-report. We also provided data on $\mathrm{OA}$ rate at the individual level in fluoride endemic areas as well as exposure rate at the individual level (UF concentration) with regards to the community level of exposure. Considering an association between fluoride and $O A$, our study design is better than the previous ones to address this issue. Finally, it is commonly known that age, gender, and body weight are personal level risk factors for OA [35-37]. We believe that, by performing stratification analysis on these variables, we had overcome the issue of confounding and effect modification, at least to a certain extent.

\section{Conclusion}

Fluoride may be a serious independent risk factor for OA disease despite taking into account other factors such as age, gender, and body weight. Our findings suggest an additional effect on the risk of OA, particularly in a non-obese adult woman $\leq 60$-year where OA risk is twelvefold. However, our results should be interpreted with caution and we recommend other large-scale cohort studies. Nonetheless, we would like to raise awareness of the healthcare professionals on the possible existence of fluorotic osteoarthritis, especially in endemic areas.

\section{Abbreviations}

OA: Osteoarthritis; SF: Skeletal Fluorosis; UF: Urinary Fluoride; BMI: Body Mass Index; Cl: Confidence Interval; OR: Odds Ratio; SD: Standard Deviation; Q: Quartile; US: United State; HLG: High Level group; LLG: Low Level Group.

\section{Declarations}

\section{Acknowledgement}


We would like to thank the residents of Tongyu County especially those participants that have been included in this study. We are grateful to the authorities of Baicheng city and of the local Center of Endemic Disease Control for theirs supports and assistance. The authors also wish to thank Justina Ucheojor Onwuka, Caselia Akiti, and Michael Boah for their comments on the draft manuscript.

\section{Author's contribution}

AS: Contributed to study design, investigation, statistical analysis, writing-original draft and interpretation. $\mathrm{XM}$ : Contributed to investigation and project management. NZ, and YM: Contributed to investigation. AL, JW, and HL: Contributed to statistical analysis and verification. JP: Conceptualization, resources, funding acquisition, writing-review, and editing and supervision. All authors discussed the results, gave comments and approved the final manuscript.

\section{Funding}

This work was supported by National Natural Science Foundation of China (81773468 and 811302389 ), the Wu Liande Science Foundation of Harbin Medical University (Grant No. WLD-QN1703), and Postdoctoral Scientific Research Developmental Fund of Heilongjiang Province (LBH-Q17092).

\section{Availability of data and materials}

The dataset used and analyzed in this study is available from the authors in reasonable request.

\section{Ethics approval and consent to participate}

The study was approved by the Ethical Review Board of Harbin Medical University (HMUIRB20120021). Written informed consent was obtained from each participant of the study population.

\section{Consent for publication}

Not applicable.

\section{Competing interests}

The authors declare to have no competing interests.

\section{References}

1. Jha SK, Singh RK, Damodaran T, Mishra VK, Sharma DK, Rai D. Fluoride in groundwater: toxicological exposure and remedies. J Toxicol Environ Health B Crit Rev. 2013;16(1):52-66. http://doi:10.1080/10937404.2013.769420

2. Namkaew M, Wiwatanadate P. Association of fluoride in water for consumption and chronic pain of body parts in residents of San Kamphaeng district, Chiang Mai, Thailand. Trop Med Int Health. 2012 Sep;17(9):1171-6. doi: 10.1111/j.1365-3156.2012.03061.x. 
3. World Health Organization. (2019). Preventing disease through healthy environments: inadequate or excess fluoride: a major public health concern. Available from: https://apps.who.int/iris/handle/10665/329484 [ Accessed Jully 16 2020].

4. Sellami M, Riahi H, Maatallah K, Ferjani H, Bouaziz MC, Ladeb MF. Skeletal fluorosis: don't miss the diagnosis! Skeletal Radiol. 2020 Mar;49(3):345-357. doi: 10.1007/s00256-019-03302-0.

5. Jolly SS, Singh BM, Mathur OC. Endemic fluorosis in Punjab (India). Am J Med. 1969 Oct; 47(4):55363. doi:10.1016/0002-9343(69)90186-7.

6. Choubisa SL. Endemic fluorosis in southern Rajasthan, Indian. International Society for Fluoride research. Report 61. 2001.

7. Gopalakrishnan, S.B., Viswanathan, G. \& Siva llango, S. Prevalence of fluorosis and identification of fluoride endemic areas in Manur block of Tirunelveli District, Tamil Nadu, South India. App/ Water Sci2, 235-243 (2012). https://doi.org/10.1007/s13201-012-0043-4

8. Krishnamachari KA. Skeletal fluorosis in humans: a review of recent progress in the understanding of the disease. Prog Food Nutr Sci. 1986;10(3-4):279-314.

9. Tucci JR, Whitford GM, McAlister WH, Novack DV, Mumm S, Keaveny TM, et al. Skeletal Fluorosis Due To Inhalation Abuse of a Difluoroethane-Containing Computer Cleaner. J Bone Miner Res. 2017 Jan;32(1):188-195. doi: 10.1002/jbmr.2923.

10. Teotia SP, Teotia M. Secondary hyperparathyroidism in patients with endemic skeletal fluorosis. $\mathrm{Br}$ Med J. 1973;1(5854):637-640. doi:10.1136/bmj.1.5854.637

11. Pei J, Li B, Liu Y, Liu X, Li M, Chu Y, et al.Matrix Metallopeptidase-2 Gene rs2287074 Polymorphism is Associated with Brick Tea Skeletal Fluorosis in Tibetans and Kazaks, China. Sci Rep 7, 40086 (2017). https://doi.org/10.1038/srep40086.

12. Izuora K, Twombly JG, Whitford GM, Demertzis J, Pacifici R, Whyte MP. Skeletal fluorosis from brewed tea. J Clin Endocrinol Metab. 2011 Aug;96(8):2318-24. doi: 10.1210/jc.2010-2891.

13. Waldbott George L. The preskeletal phase of chronic fluoride intoxication. International Society for Fluoride research 1998. 31(1): p. 13-20. From http://www.fluoridation.com/waldbot.htm [Accessed May 10 2021].

14. Roschger P, Fratzl P, Schreiber S, Kalchhauser G, Plenk H, Koller K, et al., Bone mineral structure after six years fluoride treatment investigated by backscattered electron imaging (BSEI) and small angle Xray scattering (SAXS): A case report.Bone. 1995 March 16(3):407.

15. Luo R, Liu RG, Ye C, Yu Y, Guan ZZ. Total knee arthroplasty for the treatment of knee osteoarthritis caused by endemic skeletal fluorosis. Chinese Journal of Tissue Engineering Research. 2012. From https://fluoridefreeaustralia.org/wp-content/uploads/2019/08/Luo-2012.pdf [Accessed June 10 2020].

16. Savas S, Cetin M, Akdoğan M, Heybeli N. Endemic fluorosis in Turkish patients: relationship with knee osteoarthritis. Rheumatol Int. 2001 Sep;21(1):30-5. doi:10.1007/s002960100132. 
17. CDC A National Public Health Agenda for Osteoarthritis 2010 from https://www.cdc.gov/arthritis/publications/pdf/agenda-osteoarthritis.pdf [Accessed on July 16 2020]

18. Loeser RF, Goldring SR, Scanzello CR, Goldring MB. Osteoarthritis: a disease of the joint as an organ. Arthritis Rheum. 2012 Jun;64(6):1697-707. doi: 10.1002/art.34453.

19. Long H, Zeng X, Liu Q, Wang H, Vos T, Hou Y, et al. Burden of osteoarthritis in China, 1990-2017: findings from the Global Burden of Disease Study 2017. The Lancet Rheumatology 2020 March;2(3): e164-e172. https://doi.org/10.1016/S2665-9913(19)30145-6.

20. Xu JC, Wang YZ, Xue DM, Xin SZ, Dai RT, Zhang ZL, et al. X-ray findings and pathological basis of bone fluorosis. Chin Med J (Engl). 1987 Jan;100(1):8-16.

21. Su WM, Liu RG, Ye C, Yu YN, Guan ZZ, Total hip arthroplasty for the treatment of severe hip osteoarthritis due to fluorosis. Chinese Journal of Tissue Engineering Research. 2012 February 26;16(9):1543-44.

22. Chen X, Radiological Analysis of Fluorotic Elbow Arthritis.Journal of Guiyang Medical College. 1988 13(2):303-305.

23. Bao W, Liu N, Gao B, Sun X, Dend Q. Epidemiological Observations on the Relationship between Fluorosis and Osteoarthritis. Chinese Journal of Endemiology. 2003 November;22(6):517-18.

24. Fluoride Action Network. Fluoride and Osteoarthritis, Available from http://fluoridealert.org/studies/arthritis02/._[Accessed February 2 2021].

25. National Research Council. 2006. Fluoride in Drinking Water: A Scientific Review of EPA's Standards. Washington, DC: The National Academies Press. https://doi.org/10.17226/11571

26. Duell PB, Chesnut $\mathrm{CH}$ 3rd. Exacerbation of rheumatoid arthritis by sodium fluoride treatment of osteoporosis. Arch Intern Med. 1991 Apr;151(4):783-4.

27. Adachi JD, Bell MJ, Bensen WG, Bianchi F, Cividino A, Sebaldt RJ et al. Fluoride therapy in prevention of rheumatoid arthritis induced bone loss. J Rheumatol. 1997 Dec;24(12):2308-13.

28. Dean AG, Sullivan KM, Soe MM. Open Epi: Open Source Epidemiologic Statistics for Public Health, Version. www.OpenEpi.com, updated 2013/04/06. [Accessed June 16 2019].

29. Czerwinski E, Nowak J, Dabrowska D, Skolarczyk A, Kita B, Ksiezyk M. Bone and joint pathology in fluoride-exposed workers. Arch Environ Health. 1988 Sep-Oct;43(5):340-3. doi: 10.1080/00039896.1988.9934945.

30. Heidari B., Knee osteoarthritis prevalence, risk factors, pathogenesis and features: Part I. Caspian J Intern Med. 2011;2(2):205-212.

31. Spitaels D Mamouris P, Vaes B, Smeets M, Luyten F, Hermens R, et al. Epidemiology of knee osteoarthritis in general practice: a registry-based study. BMJ Open 2020; 10: e031734. http://doi:10.1136/bmjopen-2019-031734 
32. Zipkin I, Likins RC, McClure FJ, Steere AC. Urinary fluoride levels associated with use of fluoridated waters. Public Health Rep. 1956;71(8):767-72.

33. ChineseStandard.net. Determination of fluoride in urine. Ion selective electrode method. Available from https://www.chinesestandard.net/PDF/English.aspx/WST89-2015 [Accessed January 22020 ]

34. Kellgren JH, Lawrence JS. Radiological assessment of osteo-arthrosis.Ann Rheum Dis 1957; 16(4): p. 494-502. doi: 10.1136/ard.16.4.494.

35. Cui A, Li H, Wang D, Zhong J, Chen Y, Lu H. Global, regional prevalence, incidence and risk factors of knee osteoarthritis in population-based studies. EClinicalMedicine. 2020;29-30:100587. 2020 Nov 26. doi: 10.1016/j.eclinm.2020.100587

36. Nawar M. Abed, Rami M. Adil Al-Hayali. Risk factors of hand osteoarthritis. International Journal of Development Research. 2019; 09(01):25351-25363.

37. Palazzo C, Nguyen C, Lefevre-Colau MM, Rannou F, Poiraudeau S. Risk factors and burden of osteoarthritis. Ann Phys Rehabil Med. 2016 Jun;59(3):134-138. doi: 10.1016/j.rehab.2016.01.006.

38. R Core Team. R: A language and environment for statistical computing R Foundation for Statistical Computing. 2020 Vienna, Austria. https://www.R-project.org/.

39. Bang S, Boivin G, Gerster JC, Baud CA. Distribution of fluoride in calcified cartilage of a fluoridetreated osteoporotic patient. Bone. 1985;6(4):207-10. doi: 10.1016/8756-3282(85)90002-x.

40. Lau KH, Farley JR, Freeman TK, Baylink DJ. A proposed mechanism of the mitogenic action of fluoride on bone cells: inhibition of the activity of an osteoblastic acid phosphatase. Metabolism. 1989 Sep;38(9):858-68. doi: 10.1016/0026-0495(89)90232-1.

41. Gruber HE, Baylink DJ. The effects of fluoride on bone. Clin Orthop Relat Res. 1991 Jun;(267):26477.

42. Boivin G, Chavassieux P, Chapuy MC, Baud CA, Meunier PJ. Skeletal fluorosis: histomorphometric analysis of bone changes and bone fluoride content in 29 patients. Bone. 1989;10(2):89-99. doi: 10.1016/8756-3282(89)90004-5.

43. Zhang Y, Jordan JM. Epidemiology of osteoarthritis. Clin Geriatr Med. 2010 Aug;26(3):355-69. doi: 10.1016/j.cger.2010.03.001.

44. Eaton CB. Obesity as a risk factor for osteoarthritis: mechanical versus metabolic. Med Health R I. 2004 Jul;87(7):201-4.

45. Richards A, Mosekilde L, Søgaard $\mathrm{CH}$. Normal age-related changes in fluoride content of vertebral trabecular bone-relation to bone quality. Bone. 1994 Jan-Feb;15(1):21-6. doi: 10.1016/87563282(94)90886-9.

46. Weidmann SM, Weatherell JA: The uptake and distribution of fluoride in bones. J Pathol Bacteriol 1959;78: 243-255. 
47. Meng X, Yao Y, Ma Y, Zhong N, Alphonse S, Pei J. Effect of fluoride in drinking water on the level of 5methylcytosine in human and blood. Environ Toxicol Pharmacol. 2021 Jan: 81:103511. doi: 10.1016/j.etap.2020.103511.

48. Buzalaf MAR, Whitford GM. Fluoride metabolism. Monogr Oral Sci. 2011; 22:20-36. http://doi:10.1159/000325107

\section{Tables}

Table 1 Comparison of population characteristics among cases and control groups, Tongyu county 2019 


\begin{tabular}{|c|c|c|c|c|c|}
\hline \multirow[t]{2}{*}{ Characteristics } & \multirow[t]{2}{*}{ Category } & \multirow{2}{*}{$\begin{array}{l}\text { Study Sample } \\
\mathrm{N}=372\end{array}$} & \multirow{2}{*}{$\begin{array}{l}\text { OA cases } \\
\mathrm{N}=186\end{array}$} & \multirow{2}{*}{$\begin{array}{l}\text { Control } \\
N=186\end{array}$} & \multirow[t]{2}{*}{$p$-value } \\
\hline & & & & & \\
\hline \multirow[t]{2}{*}{$\mathrm{UF}(\mathrm{mg} / \mathrm{L})$} & & 372 & 186 & 186 & $0.002^{*}$ \\
\hline & & $2.54( \pm 1.22)$ & $2.73( \pm 1.18)$ & $2.35( \pm 1.24)$ & \\
\hline DWD & & 372 & 186 & 186 & 0.457 \\
\hline (*1000mL/day) & & $1.40( \pm 1.10)$ & $1.44( \pm 1.20)$ & $1.35( \pm 0.97)$ & \\
\hline Duration living & & 372 & 186 & 186 & $0.000^{*}$ \\
\hline (year) & & $53.36( \pm 14.71)$ & $56.39( \pm 12.78)$ & $50.33( \pm 15.88)$ & \\
\hline \multirow[t]{4}{*}{ Age } & & 372 & 186 & 186 & \\
\hline & Mean-age & $60.99( \pm 9.32)$ & $63.22( \pm 7.71)$ & $58.77( \pm 10.23)$ & $0.000^{*}$ \\
\hline & Adult $\leq 60$ & $157(42.20 \%)$ & $62(39.49 \%)$ & $95(60.51 \%)$ & \\
\hline & Adult over 60 & $215(57.80 \%)$ & $124(57.67 \%)$ & $91(42.33 \%)$ & $0.000^{*}$ \\
\hline \multirow[t]{4}{*}{ BMI (kg/m2) } & & 372 & 186 & 186 & \\
\hline & Mean-BMI & $25.32( \pm 3.82)$ & $25.44( \pm 3.82)$ & $25.20( \pm 3.82)$ & 0.541 \\
\hline & No-obese & $258(69.35 \%)$ & 131(50.78\%) & $127(49.22 \%)$ & \\
\hline & Obese & $114(30.65 \%)$ & $55(48.25 \%)$ & $59(51.75 \%)$ & 0.652 \\
\hline \multirow[t]{3}{*}{ Gender } & & 372 & 186 & 186 & 1 \\
\hline & Male & 142(38.17\%) & $71(50.00 \%)$ & $71(50.00 \%)$ & \\
\hline & Female & $230(61.83 \%)$ & $115(50.00 \%)$ & $115(50.00 \%)$ & \\
\hline Income & & 372 & 186 & 186 & 0.066 \\
\hline (*10000¥/year) & & $1.25( \pm 1.78)$ & $1.09( \pm 1.66)$ & $1.42( \pm 1.89)$ & \\
\hline \multirow[t]{3}{*}{ Med history } & & 372 & 186 & 186 & 1 \\
\hline & No & $280(75.27 \%)$ & $140(50.00 \%)$ & $140(50.00 \%)$ & \\
\hline & Yes & $92(24.73 \%)$ & $46(50.00 \%)$ & $46(50.00 \%)$ & \\
\hline \multirow[t]{3}{*}{ Sport } & & 372 & 186 & 186 & 0.493 \\
\hline & No & $334(89.78 \%)$ & $169(50.60 \%)$ & $165(49.40 \%)$ & \\
\hline & Yes & $38(10.22 \%)$ & $17(44.74 \%)$ & $21(55.26 \%)$ & \\
\hline \multirow[t]{2}{*}{ Supplement. } & & 372 & 186 & 186 & 0.113 \\
\hline & Vitamin D & $03(0.81 \%)$ & $02(66.67 \%)$ & $01(33.33 \%)$ & \\
\hline
\end{tabular}




\begin{tabular}{|c|c|c|c|c|c|}
\hline & Calcium & $04(1.08 \%)$ & $00(0.00 \%)$ & $04(100.00 \%)$ & \\
\hline & None & $365(98.12 \%)$ & $184(50.41 \%)$ & $181(49.59 \%)$ & \\
\hline \multirow[t]{3}{*}{ Smoking } & & 372 & 186 & 186 & 0.580 \\
\hline & No & $251(67.47 \%)$ & $123(49.00 \%)$ & $128(51.00 \%)$ & \\
\hline & Yes & $121(32.53 \%)$ & $63(52.07 \%)$ & $58(47.93 \%)$ & \\
\hline \multirow[t]{3}{*}{ Alcohol } & & 372 & 186 & 186 & 1 \\
\hline & No & $280(75.27 \%)$ & $140(50.00 \%)$ & $140(50.00 \%)$ & \\
\hline & Yes & $92(24.73 \%)$ & $46(50.00 \%)$ & $46(50.00 \%)$ & \\
\hline \multirow[t]{3}{*}{ Filter use } & & 372 & 186 & 186 & 0.901 \\
\hline & No & $289(77.69 \%)$ & 145(50.17\%) & $144(49.83 \%)$ & \\
\hline & Yes & $83(22.31 \%)$ & $41(49.40 \%)$ & $42(50.60 \%)$ & \\
\hline \multirow[t]{3}{*}{ Ethnicity } & & 372 & 186 & 186 & 1 \\
\hline & Han & $363(97.58 \%)$ & 181(49.86\%) & $182(50.14 \%)$ & \\
\hline & Mongolian & $09(2.42 \%)$ & $05(55.56 \%)$ & $04(44.44 \%)$ & \\
\hline \multirow[t]{4}{*}{ Education } & & 372 & 186 & 186 & 0.554 \\
\hline & Highschoolabove & $93(25.00 \%)$ & $42(45.16 \%)$ & $51(54.84 \%)$ & \\
\hline & Primary school & $218(58.60 \%)$ & $113(51.83 \%)$ & $105(48.17 \%)$ & \\
\hline & Illiteracy & $61(16.40 \%)$ & $31(50.82 \%)$ & $30(49.18 \%)$ & \\
\hline \multirow[t]{3}{*}{ Occupation } & & 372 & 186 & 186 & 0.091 \\
\hline & Farmer & $348(93.55 \%)$ & 178(51.15\%) & $170(48.85 \%)$ & \\
\hline & Other & $24(6.45 \%)$ & 08(33.33\%) & $16(66.67 \%)$ & \\
\hline
\end{tabular}

\section{Note: Bold text with * mean p-value less than or equal to 0.05 , DWD: daily water drunk}

Table 2 Descriptive statistics for fluoride exposure measures (mg/L), Tongyu county 2019

\begin{tabular}{|llllllll|}
\hline Measure & $1^{\text {st }} \mathrm{Q}$ & Median & $\mathrm{SD}$ & Arithmetic mean & $3^{\text {rd }} \mathrm{Q}$ & Min. & Max. \\
\hline UF & 1.61 & 2.38 & 1.22 & 2.54 & 3.30 & 0.35 & 7.01 \\
\hline Water fluoride & 1.35 & 1.38 & 0.32 & 1.49 & 1.57 & 0.94 & 2.30 \\
\hline
\end{tabular}

Note: SD: standard deviation, Q: quartile, UF: urinary fluoride

Table 3 OA subtype rate among cases, Tongyu county 2019 


\begin{tabular}{|c|c|c|}
\hline OA type & Sample estimates with $95 \% \mathrm{Cl}$ & $p$-value \\
\hline Knee joint OA & $73.12 \%(66.04,79.22)$ & 0.000 \\
\hline Elbow joint $O A$ & $04.30 \%(02.01,08.60)$ & 0.000 \\
\hline Knee and elbow OA & $22.58 \%(16.92,29.39)$ & 0.000 \\
\hline
\end{tabular}

Test: prop.test used for estimates

Table 4 Unadjusted association between fluoride exposure level and OA in full sample, Tongyu county 2019

\begin{tabular}{|llll|}
\hline Models & Category & OR $(95 \% \mathrm{Cl})$ & p-value \\
\hline Model1 & Each $1 \mathrm{mg} / \mathrm{L}$ increase & $1.30(1.09,1.55)$ & $\mathbf{0 . 0 0 3}^{*}$ \\
& & & \\
& LLG & & \\
& HLG & $1.77(0.57,1.03)$ & 0.079 \\
Model3 & & & \\
& & $1.11,2.53)$ & $\mathbf{0 . 0 1 3 ^ { * }}$ \\
& $1^{\text {st }} \mathrm{Q}$ & 1 (reference $)$ & - \\
& $2^{\text {nd }} \mathrm{Q}$ & $1.68(0.94,3.04)$ & 0.080 \\
& $3^{\text {rd }} \mathrm{Q}$ & $1.87(1.05,3.38)$ & $\mathbf{0 . 0 3 4 ^ { * }}$ \\
& $4^{\text {th }} \mathrm{Q}$ & $2.55(1.42,4.63)$ & $\mathbf{0 . 0 0 1 ^ { * }}$ \\
\hline
\end{tabular}

Note: Bold text with ${ }^{*}$ mean $p$-value less than or equal to 0.05

Model2: HLG mean UF > 2.38mg/L, and LLG mean UF $\leq 2.38 \mathrm{mg} / \mathrm{L}$ (median value)

Table 5 Adjusted association between fluoride exposure level and OA in full sample, Tongyu county 2019 


\begin{tabular}{|c|c|c|c|}
\hline Models & Category & OR (95\% Cl) & $p$-value \\
\hline \multicolumn{4}{|c|}{ (a) adjustment } \\
\hline & $1^{\text {st }} \mathrm{Q}$ & 1 (reference) & - \\
\hline & $2^{\text {nd }} Q$ & $1.60(0.88,2.92)$ & 0.122 \\
\hline & $3^{\text {rd }} Q$ & $1.73(0.95,3.18)$ & 0.071 \\
\hline & 4th Q & $2.38(1.31,4.36)$ & $0.004^{*}$ \\
\hline \multicolumn{4}{|c|}{ (b) adjustment } \\
\hline & $1^{\text {st }} \mathrm{Q}$ & 1 (reference) & - \\
\hline & $2^{\text {nd }} Q$ & $1.71(0.94,3.13)$ & 0.080 \\
\hline & $3^{\text {rd }} Q$ & $1.84(1.01,3.39)$ & $0.048^{*}$ \\
\hline & $4^{\text {th }} \mathrm{Q}$ & $2.51(1.37,4.67)$ & $0.003^{*}$ \\
\hline \multicolumn{4}{|c|}{ (c) adjustment } \\
\hline & $1^{\text {st }} \mathrm{Q}$ & 1 (reference) & - \\
\hline & $2^{\text {nd }} Q$ & $1.63(0.89,3.00)$ & 0.109 \\
\hline & $3^{\text {rd }} Q$ & $1.80(0.98,3.33)$ & 0.059 \\
\hline & $4^{\text {th }} \mathrm{Q}$ & $2.46(1.34,4.57)$ & $0.003^{*}$ \\
\hline
\end{tabular}

Note: Bold text with * mean p-value less than or equal to 0.05

(a) Adjusted for age, gender and BMI

(b) Adjusted for duration of living, daily water drunk, income, sport and filter use

(c) Adjusted for age, gender, BMI, daily water drunk, income, sport and filter use

Table 6 Adjusted association between fluoride exposure and OA in full sample, Tongyu county 2019 


\begin{tabular}{|lll|}
\hline Models & OR $(\mathbf{9 5} \% \mathrm{Cl})$, & p-value \\
\hline & UF (for each $1 \mathrm{mg} / \mathrm{L}$ increase) & \\
\hline (a) adjustment & $1.26(1.06,1.51)$ & $\mathbf{0 . 0 1 0}^{*}$ \\
\hline (b) adjustment & $1.28(1.07,1.53)$ & $\mathbf{0 . 0 0 7}^{*}$ \\
\hline (c) adjustment & $1.27(1.06,1.52)$ & $\mathbf{0 . 0 0 8}^{*}$ \\
\hline
\end{tabular}

Note: Bold text with ${ }^{*}$ mean $p$-value less than or equal to 0.05

(a)Adjusted for age, gender and BMI

(b)Adjusted for duration of living, daily amount of water drunk, income, sport and filter use

(c)Adjusted for age, gender, BMI, daily amount of water drunk, income, sport and filter use

Table 7 Association between fluoride exposure level and OA in stratified analysis before and after adjustment, Tongyu county 2019 


\begin{tabular}{|c|c|c|c|c|c|}
\hline & \multicolumn{3}{|c|}{ Unadjusted OR } & \multicolumn{2}{|c|}{ Adjusted OR } \\
\hline & \multirow[t]{2}{*}{$\mathrm{n}:$} & \multirow[t]{2}{*}{ category } & \multirow{2}{*}{$\begin{array}{l}\text { UF (by quartile } \\
\text { group) } \\
\text { OR (95\% Cl), } \\
p \text {-value }\end{array}$} & \multirow[t]{2}{*}{ category } & \multirow{2}{*}{$\begin{array}{l}\text { UF (by } \\
\text { quartile } \\
\text { group) } \\
\text { OR (95\% } \\
\text { Cl), p- } \\
\text { value }\end{array}$} \\
\hline Stratification & & & & & \\
\hline \multicolumn{6}{|l|}{ Gender } \\
\hline \multirow[t]{7}{*}{ Female (d) } & \multirow[t]{7}{*}{230} & $1^{\text {st }} \mathrm{Q}$ & 1 (reference) & $1^{\text {st }} Q$ & 1 (reference) $^{d}$ \\
\hline & & $2^{\text {nd }} Q$ & $\begin{array}{l}1.26(0.62,2.56) \\
0.521\end{array}$ & $2^{\text {nd }} Q$ & \multirow{2}{*}{$\begin{array}{l}1.19(0.56 \\
2.52) \\
0.638\end{array}$} \\
\hline & & $3^{\text {rd }} Q$ & \multirow{2}{*}{$\begin{array}{l}2.28(1.05,5.04) \\
0.038^{\star}\end{array}$} & $3^{\text {rd }} Q$ & \\
\hline & & $4^{\text {th }} \mathrm{Q}$ & & \multirow[t]{4}{*}{$4^{\text {th }} \mathrm{Q}$} & \multirow{2}{*}{$\begin{array}{l}2.37(1.03 \\
5.57) \\
\mathbf{0 . 0 4 3}^{*}\end{array}$} \\
\hline & & & \multirow{3}{*}{$\begin{array}{l}2.15(1.04,4.50) \\
0.038^{*}\end{array}$} & & \\
\hline & & & & & $\begin{array}{l}2.18(1.01, \\
4.79)\end{array}$ \\
\hline & & & & & $0.048^{*}$ \\
\hline \multirow[t]{6}{*}{ Male (d) } & \multirow[t]{6}{*}{142} & $1^{\text {st }} Q$ & 1 (reference) & $1^{\text {st }} \mathrm{Q}$ & 1 (reference) $^{d}$ \\
\hline & & $2^{\text {nd }} Q$ & $\begin{array}{l}3.24(1.13,9.77) \\
0.031^{*}\end{array}$ & $2^{\text {nd }} Q$ & $\begin{array}{l}5.20(1.64 \\
17.93)\end{array}$ \\
\hline & & & $\begin{array}{l}1.77(0.70,4.68) \\
0.232\end{array}$ & $3^{\text {rd }} Q$ & $0.006^{*}$ \\
\hline & & $4^{\text {th }} \mathrm{Q}$ & \multirow{3}{*}{$\begin{array}{l}3.55(1.31,10.17) \\
0.014^{*}\end{array}$} & $4^{\text {th }} \mathrm{Q}$ & $\begin{array}{l}2.05(0.74 \\
5.94) \\
0.169\end{array}$ \\
\hline & & & & & $\begin{array}{l}4.76(1.59 \\
15.30)\end{array}$ \\
\hline & & & & & $0.006^{*}$ \\
\hline \multicolumn{6}{|l|}{ BMI } \\
\hline \multirow[t]{5}{*}{ Obese (e) } & \multirow[t]{5}{*}{114} & $1^{\text {st }} \mathrm{Q}$ & 1 (reference) & $1^{\text {st }} \mathrm{Q}$ & 1 (reference) $^{e}$ \\
\hline & & $2^{\text {nd }} Q$ & $\begin{array}{l}1.11(0.39,3.19) \\
0.836\end{array}$ & $2^{\text {nd }} Q$ & $\begin{array}{l}1.25(0.41, \\
3.88)\end{array}$ \\
\hline & & $3^{\text {rd }} Q$ & $1.61(0.53,5.02)$ & $3^{\text {rd }} Q$ & 0.688 \\
\hline & & $4^{\text {th }} \mathrm{Q}$ & $\begin{array}{l}0.83(0.27,2.49) \\
0.745\end{array}$ & $4^{\text {th }} \mathrm{Q}$ & $\begin{array}{l}2.10(0.63 \\
7.25) \\
0.228\end{array}$ \\
\hline & & & & & $\begin{array}{l}1.06(0.32 \\
3.48) \\
0.919\end{array}$ \\
\hline Non-obese (e) & 258 & $1^{\text {st }} Q$ & 1 (reference) & $1^{\text {st }} Q$ & 1 (reference) $\mathrm{e}$ \\
\hline
\end{tabular}




\begin{tabular}{|c|c|c|c|}
\hline $2^{\text {nd }} Q$ & $\begin{array}{l}1.98(0.97,4.10) \\
0.060\end{array}$ & $2^{\text {nd }} Q$ & \multirow[t]{2}{*}{$\begin{array}{l}1.86(0.88, \\
3.99) \\
0.105\end{array}$} \\
\hline $3^{\text {rd }} Q$ & \multirow{2}{*}{$\begin{array}{l}1.97(0.99,3.96) \\
0.052\end{array}$} & $3^{\text {rd }} Q$ & \\
\hline \multirow[t]{4}{*}{$4^{\text {th }} \mathrm{Q}$} & & $4^{\text {th }} \mathrm{Q}$ & $\begin{array}{l}1.76(0.84, \\
3.72)\end{array}$ \\
\hline & \multirow{3}{*}{$\begin{array}{l}4.21(2.07,8.84) \\
0.000^{*}\end{array}$} & & 0.131 \\
\hline & & & $\begin{array}{l}3.99(1.86, \\
8.82)\end{array}$ \\
\hline & & & $0.000^{*}$ \\
\hline
\end{tabular}

Age

Adult over 60 (f)

$2151^{\text {st }} \mathrm{Q}$

1 (reference)

$1^{\text {st }} \mathrm{Q}$

1 (reference) $^{f}$

$\begin{array}{ll}2^{\text {nd }} \mathrm{Q} & \begin{array}{ll}1.07(0.47,2.41) \\ \end{array}\end{array}$

$2^{\text {nd }} \mathrm{Q}$

1.25 (0.54,

$$
3^{\text {rd }} \mathrm{Q}
$$

$0.93(0.42,2.03)$

$3^{\text {rd }} \mathrm{Q}$

2.91)

$4^{\text {th }} \mathrm{Q}$

$$
0.854
$$

$1.15(0.52,2.57)$

$4^{\text {th }} \mathrm{Q}$

$1.17(0.50$,

0.720

2.70)

0.711

1.29 (0.56,

2.99)

0.538

Adult $\leq 60$ (f)

$157 \quad 1^{\text {st }} \mathrm{Q}$

1 (reference)

$2^{\text {nd }} \mathrm{Q}$

$2.50(0.98,6.61)$

$3^{\text {rd }} Q$

0.057

$1^{\text {st }} \mathrm{Q}$

1 (reference) $^{f}$

$4^{\text {th }} \mathrm{Q}$

$3.76(1.44,10.26)$

$\mathbf{0 . 0 0 7 ^ { * }}$

$6.00(2.34,16.41)$

$0.000^{*}$

3.11 (1.10,

9.18)

$2^{\text {nd }} \mathrm{Q}$

$0.034^{*}$

$3^{\text {rd }} \mathrm{Q}$

$4^{\text {th }} \mathrm{Q}$

4.90 (1.66,

15.39)

$0.005^{*}$

7.69 (2.58, 25.05)

$0.000^{*}$

Non-obese adult women $\leq 60(h)$

\begin{tabular}{|c|c|c|c|}
\hline $1^{\text {st }} \mathrm{Q}$ & 1 (reference) & $1^{\text {st }} \mathrm{Q}$ & 1 (reference) \\
\hline $2^{\text {nd }} Q$ & $\begin{array}{l}2.74(0.58,15.08) \\
0.211\end{array}$ & $2^{\text {nd }} Q$ & \multirow{2}{*}{$\begin{array}{l}4.58(0.84 \\
29.86) \\
0.086\end{array}$} \\
\hline $3^{\text {rd }} Q$ & $\begin{array}{l}4.79(0.96,28.07) \\
0.061\end{array}$ & $3^{\text {rd }} Q$ & \\
\hline $4^{\text {th }} \mathrm{Q}$ & \multirow[t]{2}{*}{$\begin{array}{l}10.22(2.24,59.29) \\
\mathbf{0 . 0 0 4}^{*}\end{array}$} & $4^{\text {th }} \mathrm{Q}$ & $\begin{array}{l}8.06(1.22 \\
67.29) \\
0.037^{*}\end{array}$ \\
\hline & & & $\begin{array}{l}12.55(2.15 \\
99.65) \\
\mathbf{0 . 0 0 8}^{*}\end{array}$ \\
\hline
\end{tabular}

72 
Note: Bold text with * mean p-value less than or equal to 0.05

(d)Adjusted for BMI, age, income, daily water drunk, sport and filter use

(e)Adjusted for age, gender, income, daily water drunk, sport and filter use

(f)Adjusted for BMl, gender, income, duration of living, daily water drunk, sport and filter use

(h) Adjusted for duration of living, daily water drunk, income, sport and filter use

\section{Supplementary Files}

This is a list of supplementary files associated with this preprint. Click to download.

- Additionalfilefigure1.docx 